Finally, did you see either intraventricular or subarachnoid bleeding?

R. E. Myers: Dr. BRANN, who follows the asphyxiated newborn monkeys very, very carefully in the nursery, including their blood status, their clinical status, etc., has become aware of a clinical course post-asphyxia similar to that you have described in relation to the human; namely, monkey infants, assaulted at birth with prolonged partial asphyxia, frequently seem to do quite well in the nursery for the first 24 to 36 hours. However, at about this time, these animals frequently exhibit a progressive downhill course, with seizures, depression of consciousness, and finally death within the next 12 to 24 hours.

This phenomenon is familiar also in the newborn monkey nursery in animals receiving prolonged chronic hypoxia. In recent conversations, Dr. BuchanaN in Chicago has described the selfsame clinical course exhibited by the infants of human mothers who have received large doses of demerol during the course of labor. He suggested that such mothers may exhibit some degree of hypotension which, in turn, may damage the baby. He described these babies as appearing well during the first day, but thereafter deteriorating over the following 24 to 48 hours and ultimately exhibiting damage to the brain.

It is reassuring to us to come to the realization that the same circumstance that we have observed in our monkey babies also occurs in the human who has received some asphyctic compromise. We needed your words and the words of Dr. Buchanan to confirm what we were seeing. We can now examine this phenomenon further and, perhaps, achieve some understanding of its mechanism and significance.

Have cerebral decongestants been tried in an effort to determine whether the damage to the brain could be, thereby, ameliorated or prevented? We have not carried out such studies since we are still attempting to gain insights into the occurrence of brain swelling itself and the mechanisms through which it is brought about. Your suggestion may serve as a lead for further studies.

Is the swelling of the brain itself deleterious? We certainly think so. Animals who exhibit more than a moderate degree of brain swelling are also resistant to perfusion of their brains with fixatives at the autopsy table at the time of their sacrifice. Instead of the blood being washed from such brains under perfusion pressure, the squeezed-out blood remains within the cerebral vessels. We take this failure of perfusion of the swollen brain to indicate that there has been a direct and severe interference with circulation through portions or all of the brain. We believe that the remarkable and severe patterns of cerebral necrosis which we have demonstrated are probably due to failure of circulation of the blood secondary to brain swelling. Hence, regional failure of perfusion, we believe, is directly tied into the production and distribution of patterns of damage to the brain in relation to the fetus undergoing compromise in relation to hypoxic insult.

M.E.Towell (University of British Columbia, Vancouver): You mentioned that you had catheters in fetal vessels to monitor blood gases. Was there any interference with blood flow through the brain by placement of catheters in the carotid or jugular vessels?

R.E. MYERS: The catheters were introduced into the femoral vessels and threaded anteriorly until their tips lay within the major vessels in the thorax. It seems unlikely from the placement of the catheter tips that direct blockage of blood flow to the major vessels in the neck could have played a role in the production of brain damage.

\title{
INDEX OF ABSTRACTS
}

(Numbers following entries refer to abstract number)

Acid-Base metabolism 23, 31, 37, 38

Acidosis 4, 8, 16

ADAm, P.A.J. 7, 32

ADAMSONS, K. 8, 38

ALEXANDER, H.E. 18

Alpert, J. 1

Aminoaciduria 11, 16

Anemia 24

Angle, C. R. 30

AnTHony, B.F. 17

Antibody, secretory 15

Anti-streptolysin-O 17

Asphyxia, 4, 38

Ayour, E.M. 17

BEARD, R.W. 38

BeaudRx, P.H. 9

Behavior 30

Beran, A.V. 33

Bergstrom, W.H. 16

BERMAN, J.L. 12

Bicarbonate transport 16

Bladder 5
Blastogenesis 25

Blood 23

Bowe, E.T. 8

Brain 29, 38

Gadman, T.E. 29

Calciferol 16

Cancer 14

Cerebral circulation 29

Chapman, S.S. 17

Chase, H.P. 28

Childs, B. 21

Chondroitin sulfate 13

GLARK, L. C. Jr. 33

Convulsions 2

Gunningham, G.C. 12

Cystathionine synthatase 11

Cytomegalovirus 26

D'Amodio, M.D. 22

DANIEL, S.S. 4

Davidson, W. 35

DAY, R.W. 12

Deoxyribonucleic acid, transforming 18
Der Kaloustian, V.M. 21

Developmental biochemistry $19,20,22$

Developmental physiology 31

Diabetes

- insipidus 6

- mellitus 32,34

Drazfalusy, E. 20

Diet 35

Differentiation, cellular 19

Digitalis 37

DORFMAN, A. 13

Drash, A. 6

Edelmann, C. M., Jr. 31

Enuresis 5

Esperanca, M. 5

Estradiol 19

Fetus 7

FINSTER, M. 8

GANDY, G.M. 23

GARCES, L.Y. 6

GAULL, G.E. 11 


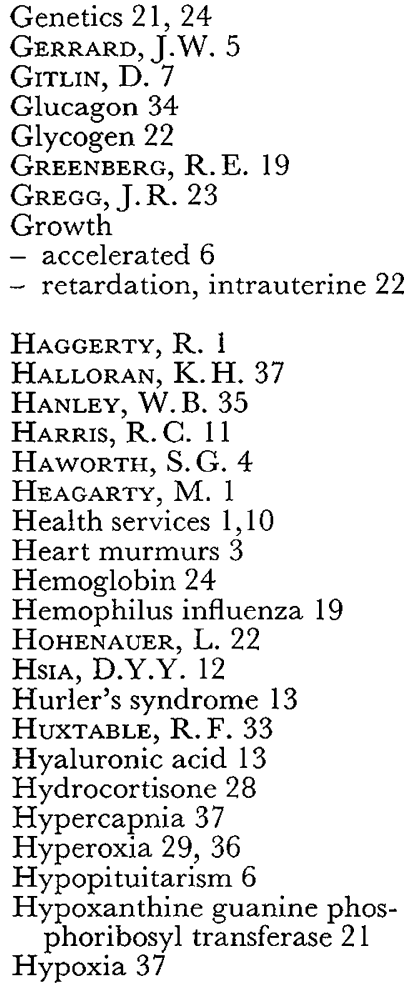

Immunity 15,17

Immunoglobulins 15

Infection 17

- recurrent 27

Inherited disease 14

Insulin 7, 32, 34

Intelligence 35

JAMES, L.S. 4,8

JEHLE, J.W. 29

KAN, Y.W. 24

KaPLAN, E.L. 17

KARZON, D.T. 15

KatURICh, N. 33

KAYE, R. 27

Kennedy, C. 29

KENNY, F.M. 6

16-Keto-androstenediol 20

Kidney 31

- disease 16

KING, K. G. 32

Kohrman, A. 19

KosA, J. 1

LANG, D.J. 26

LAWRENCE, A. M. 34

LEIDY, G. 18
Lesch-Nyhan's syndrome 21

Leukocytes 26, 27

LEVITSKY, L. 27

Liebman, J. 3

LiNSAO, L.S. 35

LISCHNER, H.W. 25

Lung 36

Lymphocytes 25

MacGillivrax, M. 15

Malignancy 14

Malnutrition 35

Mancuso, S. 20

Marfan's syndrome 13

Matalon, R. 13

MaCollum, A.T. 10

MaInTIRe, M.S. 30

MaKinley, F.W. 18

MeILE, R. L. 30

Metabolism

- carbohydrate 22

- glucose 7, 32, 34

Metcoff, J. 22

Methimazole 28

Methioninemia 11

Microorganisms 18

Micturition 5

Migeon, B. R. 21

MilleR, M.E. 27

Miller, R.W. 14

Moes, G. A. F. 35

Mucopolysaccharides 13

Myers, R.E. 38

Nathan, D. G. 24

Neurolipids 28

Newborn 4, 8, 9, 29, 32, 33, 38

Nicolas, J.G. 37

Noren, B. 26

NyHan, W.L. 21

Obesity 34

OGRA, P.L. 15

OH, W. 22

Opsonin 27

OUTERBRIDGe, E.W. 9

Oxygenation 33

Oxytocin 38

Parturition 8

Paulsen, E. P. 34

Peritoneum 23

Phagocytosis 25, 27

Phenylalanine 12, 35

Phenylketonuria 12,35

Placenta 7, 20

Plasma 27

Poisoning 30

Poliovirus 15

Poppers, P. 8

Prematurity 9

Prolactin 6
Protein

- dietary 31

- synthesis 19

Pyoderma 17

RÄIHÄ, N. 7

Ramos, A.D. 9

Renal tubules 16

Respirator, negative pressure 9

Respiratory distress syndrome $9,33,36$

Retardation, mental 12, 35

Reynolds, J.W. 20

Rickets 16

Righthand, F. 15

RoBerTSON, L. 1

Salvador, H.S. 23

SARCIA, S.R. 4

SchimpfF, S. 37

Schwartz, A.H. 10

Schwartz, E. 24

Schwartz, R. 7, 32

Seizures 30

Sokoloff, L. 29

Solomon, G. 11

Solvonuk, P.F. 23

SoOD, S. 3

STAGHURA, I. 18

STERN, L. 9

Steroidogenesis 20

Strauss, J. 33

Streptococcus 17

Sulfatide 28

Susen, A. 6

Talner, N.S. 37

Teramo, K. 7

$\alpha$-Thalassemia 24

Thymic dysplasia 25

Thyroid hormones 28

Towell, M.E. 23

Transfusion, intrauterine 23

Tyrosinosis 11

Uric acid 21

USHER, R. 36

Vaccine, polio 15

Vagina 19

VAN DEN BERG, B.J. 2

Viremia 26

Walravens, P. A. 28

WANNAMAKER, L.W. 17

WiQvist, N. 20

Wolfish, N.M. 31

YAP, L.L. 22

Yerushalmy, J. 2

Young, W.J. 21 